JSAP: Journal Syariah and Accounting Public

ISSN: 2622-3538

Available Online at https://journal.umgo.ac.id/index.php/JSAP/index

Vol. 3, No. 1 Juli 2020

DOI: $10.31314 /$ jsap.3.1.25-32.2020

\title{
KEPUASAN MASYARAKAT DALAM PENINGKATAN KESEJAHTERAAN TERHADAP SERAPAN DANA DESA DI DESA MOODULIO KECAMATAN BONE KABUPATEN BONE BOLANGO
}

\author{
Indrawati Bempa ${ }^{1}$ Harijono Imran ${ }^{2}$ Widya Kurniati Mohi ${ }^{3}$ \\ 1,2,3. Program Studi Administrasi Publik Universit Muhammadiyaah Gorontalo Indonesia \\ Email; widyakurniati@umgo.ac.id
}

Info Artikel: Diterima: 13 Februari 2020, Disetujui: 23 Februari 2020, Publish 15 Juli 2020

\begin{abstract}
:
The purpose of this research is to determine community satisfaction with the absorption of village funds in Moodulio Village, Bone District, Bone Bolango Regency. This study uses a qualitative research approach, using data sources through interviews and documentation studies. The results of the study concluded that the Village Fund Allocation (ADD) sourced from the central and regional government financial balance funds greatly affected the rate of development of each village. Likewise with Moodulio Village, Bone District, Bone Bolango Regency, with the current $A D D$, Moodulio Village is very helpful in carrying out village development in stages for the realization of community welfare.
\end{abstract}

Keywords: Satisfaction, Community, Absorption, Village Fund

\begin{abstract}
Abstrak:
Tujuan penetian ini adalah untuk mengetahui kepuasan masyarakat terhadap serapan dana desa di Desa Moodulio Kecamatan Bone Kabupaten Bone Bolango Penelitian ini menggunakan pendekatan penelitian kualitatif, dengan dengan mengunakan sumber data melalui wawancara dan studi dokumentasi. Hasil penelitian diperoleh kesimpulan bahwa Alokasi dana desa (ADD) yang bersumber dari dana perimbangan keuangan pemerintah pusat dan daerah keberadaanya sangat mempengaruhi laju pembangunan setiap desa. Demikian halnya dengan desa Moodulio Kecamatan Bone Kabupaten Bone Bolango dengan adanya ADD saat ini maka desa Moodulio sangat terbantu dalam melaksanakan pembangunan desa secara bertahap demi terwujudnya kesejahteraan masyarakat. .
\end{abstract}

Kata kunci : Kepuasan, Masyarakat, Serapan, Dana Desa

\section{PENDAHULUAN}

Desa adalah lingkup otonomi terkecil dalam hirarki pemerintahan. pada gilirannya dewasa ini desa menjadi tolak ukur terhadap sebuah sistem pemerintahan yang berbasis Local Wisdom. Sebagai patron figur pemerintahan pusat dimata masyarakat, desa memegang peranan besar untuk mendorong terwujudnya cita-cita nasional. Trend issue desa sebagai garda terdepan dalam membangun masyarakat adalah salah satu bentuk Empowerment pemerintahan desa dalam mewujudkan cita-cita tersebut. Dalam pengertiannya Desa dan atau Desa adat, adalah kesatuan masyarakat hukum yang memiliki batas wilayah yang 
berwewenang untuk mengatur dan mengurus urusan pemerintahan, kepentingan masyarakat setempat berdasarkan prakarsa masyarakat, hak asal usul, dan atau hak tradisional yang diakui dan dihormati dalam sistem pemerintahan Negara Kesatuan Republik Indonesia. Sejalan dengan mandat UU No. 6 Tahun 2014 tentang Desa bahwa Pemerintah Desa adalah penyelenggara urusan pemerintahan dan kepentingan masyarakat setempat dalam sistem pemerintahan Negara Kesatuan Republik Indonesi. Pemerintah Desa melakukan Pembangunan Desa upaya dalam peningkatan Kualitas Hidup dan kehidupan untuk sebesar-besarnya kesejahteraan masyarakat Desa. Kesejahteraan sosial mengandung arti yang luas dan mencakup berbagai segi pandangan atau ukuran-ukuran tertentu.

Sebagai bentuk peng-ejawantahan UU No. 6 Tahun 2014 tersebut bahwa desa memiliki otoritas untuk mengatur urusan rumah tangganya demi mewujudkan kesejahteraan masyarakat desa, termasuk sumber Dana Desa yang diatur dan dialokasikan dari Anggaran Pendapatan dan Belanja Negara (APBN) yang diperuntukan bagi Desa dan Desa Adat yang ditransfer melalui Anggaran Pendapatan dan Belanja Daerah Kabupaten/Kota dan digunakan untuk membiayai penyelenggaraan Pemerintahan, Pembangunan, serta Pemberdayaan Masyarakat dan Kemasyarakatan. Berdasarkan Peraturan pemerintah No 60. Tahun 2014 tentang Dana Desa yang bersumber dari APBN. Dengan luasnya lingkup kewenangan desa dan dalam rangka mengoptimalkan Penggunaan Dana Desa, maka penggunaan Dana Desa diprioritaskan untuk mebiayai pembangunan dan pemberdayaan masyarakat desa, semua ini dilakukan oleh Pemerintah Pusat agar tercipta Desa yang lebih baik, lebih maju, terutama dalam meningkatkan perekonomian masyarakat desa karena Dana Desa bertujuan untuk membangun sarana atau prasarana hingga masyarakat desa bisa terbantu dalam meningkatkan perekonomiannya.

Desa Moodulio berada di Kecamatan Bone Kabupaten Bone Bolango yang berbatasan langsung dengan Kabupaten Bolaang Mongondow Selatan, Provinsi Sulawesi Utara. Desa Moodulio telah menyelenggarakan proses pemerintahan dengan serapan dan alokasi dana desa yang bersumber dari dana APBN dan APBD Sejak tahun 2015 sampai sekarang.

1. Tahun 2015 Desa Moodulio telah mengelola Dana Desa/APBN Sebesar Rp. 200.016.000 (Dua Ratus Juta Enam Belas Ribu Rupiah), yang telah dialokasikan untuk Membangun Jalan Lingkar Akses Tani di Dusun I dan Dusun IV.(sumber data: APBDes Moodulio Tahun 2015).

2. Pada tahun 2016 desa Moodulio mengelola Dana Desa/APBN sejumlah Rp.675.882.000 (Enam Ratus Tujuh Puluh Lima Juta Delapan Ratus Delapan Puluh Dua Ribu Rupiah),yang digunakan untuk peningkatan sarana dan prasarana untuk masyarakat desa yakni Untuk Pembangunan Jalan Rabat Beton Akses Tani, pembangunan MCK + Sumur Gali dan Pengadaan Rakit/Rumpon. (sumber data: APBDes Moodulio Tahun 2016).

3. Serta pada tahap awal di Tahun 2017 dengan pengelolaan Dana Desa/APBN sebesar Rp. 775.872 .000 (Tujuh Ratus Tujuh Puluh Lima Juta Delapan Ratus Tujuh Puluh Dua Ribu Rupiah), yang digunakan untuk Pengadaan Honor Guru PAUD dan Guru Ngaji, Pengadaan Perlengkapan Sekolah Anak Miskin, Pengadaan 
Perlengkapan Rukun Duka, protes masyarakat mengenai prioritas

Pengadaan Ternak Sapi Untuk KK

Miskin, Pengadaan Lampu Penerang

Jalan, Pengadaan Alat Kesehatan

Poskesdes dan Pembangunan

Draenase.(sumber data: APBDes

Moodulio Tahun 2017).

Penyerapan anggaran desa -dalam pemanfaatannya sebagaimana diuraikan diatas-, baik Dana Desa maupun Alokasi Dana Desa ini adalah bagaian dari upaya atau pun tujuan pembangunan infrastruktur maupun peningkatan kesejahteraan masyarakat, yang notabenenya menjadi konsentrasi dan fokus dari pemerintah Desa. Meskipun demikian titik pijak dari tahapan ini adalah evaluasi terhadap proses yang telah dilakukan, yang tidak hanya berorientasi pada hasil namun juga pada subyek yang menjadi sasaran pengalokasian Dana Desa tersebut yakni Masyarakat Desa Moodulio sebagai bentuk pelayanan publik. Inti dari setiap pelayanan adalah kepuasan Stakeholder. Dan dalam konteks pelayanan publik ini masyarakat adalah stake holder utama yang harus dilayani kebutuhan maupun kepentingan yang sangat beraneka ragam dari setiap individunya, dengan tidak mengesampingkan hak dan tanggung jawab pemerintah dan pemerintahan desa Moodulio yang juga bagian dari komponen masyarakt itu sendiri.

Namun demikian pelayanan adalah tugas utama bagi pemerintah desa yang telah mendapatkan mandat dari masyarakatnya sebagai keterwakilan aspirasinya. Permasalahan klasik yang sering terjadi dari setiap bentuk pelayanan adalah ketidak puasan dari stakeholder atas pelayanan yang diberikan, yang biasanya ditunjukan dalam bentuk protes, keberatan, aksi dan lain sebagainya. Hal serupa pun dialami dan terjadi di Desa Moodulio, berbagai permasalahan yang terjadi seperti; alokasi Dana Desa, kebijakan Desa mengenai serapan dan alokasi anggaranyang dinilai masyarakat tidak sesuai peruntukannya, bahwa Dana Desa harusnya dialokasikan untuk membantu ekonomi masyarakat miskin misalnya, untuk membantu usaha maupun daya beli masyarakat, demi meningkatkan kesejahteraannya. Adanya keberatan dan protes masyarakat mengenai ketidak puasan terhadap penyelenggaraan pemerintahan desa dengan berbagai cara atau media, ataupun kelompok masyarakat tertentu yang pada dasarnya sudah mengetahui arah kebijakan namun ingin mencari celah protes. Permasalahan ketidak puasan masyarakat ini juga berimplikasi pada ketidakpercayaan masyarakat terhadap kebijakan pemerintah desa maupun penyelenggaraan pemerintahan desa..

\section{METODE PENELITIAN}

Dalam penelitian ini menggunakan pendekatan fenomenologis yakni Merupakan studi yang berusaha mencari "esensi" makna dari suatu fenomena yang dialami oleh beberapa individu. Terkait penelitian Analisis kepuasan Masyarakat terhadap serapan dana Desa di Desa Moodulio Kecamatan Bone Kabupaten Bone Bolango ini Lebih spesifik lagi menggunakan pendekatan fenomenologi transcendental yakni penelitian yang berusaha meneliti suatu fenomena dengan mengesampingkan prasangka tentang fenomena tersebut. Lokasi penelitian ini berada di Desa Moodulio, Kecamatan Bone, Kabupaten Bone Bolango, Provinsi Gorontalo, dengan fokus penelitian pada Analisis kepuasan Masyarakat terhadap serapan dana Desa di Desa Moodulio Kecamatan Bone Kabupaten Bone Bolango. 
HASIL DAN PEMBAHASAN

\section{A. Gambaran Umum Lokasi Penelitian}

Desa Moodulio adalah salah satu desa yang terletak di Kecamatan Bone Kabupaten Bone Bolango, dimana Desa Moodulio secara geografis memiliki luas wilayah 1.500 $\mathrm{Ha}$ yang berbatasan dengan beberapa desa disekitarnya yaitu:

- Sebelah Utara Berbatasan Dengan Keluarahan Pinogu

- Sebelah Selatan Berbatasan Dengan Teluk Tomini

- Sebelah Timur Berbatasan Dengan Desa Molosipat kecamatan Posigadan Kabupaten Bolaang Mongondow Selatan Provinsi Sulawesi Utara

- Sebelah Barat Berbatsan Dengan Desa muara Bone Kecamatan Bone Kabupaten Bone Bolango Provinsi Gorontalo

Desa Moodulio memiliki jumlah penduduk 928 jiwa, yang terdiri dari 488 jiwa penduduk laki-laki dan 440 jiwa penduduk perempuan.

B. Kepuasan Masyarakat Terhadap Serapan Dana Desa di Desa Moodulio Kecamatan Bone Kabupaten Bone Bolango

Sebagaimana yang telah dikemukakan pada bagian terdahulu dari bagian penelitian ini, bahwa kepuasan masyarakat merupakan respon terhadap kinerja organisasi publik dalam penelitian ini organisasi publik tersebut adalah pemerintah Desa Moodulio yang dipersepsikan sebelumnya. Tingkat kepuasan merupakan fungsi dari perbedaan antara kinerja yang dirasakan (perceived performance) dan harapan (expectation) masyarakat bisa mengalami salah satu dari tiga tingkat kepuasan yang umum. Jika kinerja di bawah harapan, masyarakat akan tidak puas. Jika kinerja sesuai dengan harapan, masyarakat akan puas. Apabila kinerja melampaui harapan, masyarakatakan sangat puas, senang, atau bahagia.

Hasil penelitian yang telah dilakukan dengan menggunakan metode wawancara kepada berbagai informan yang telah ditetapkan sebelumnya, menggambarkan presepsi masyarakat tentang kepuasan masyarakat terhadap serapan anggaran Dana Desa. Hasil wawancara ini mengacu pada 6 (enam) indikator pertanyaan sebagai berikut:

1. Proses perencanaan anggaran di Desa Moodulio Kecamatan Bone Kabupaten Bone Bolango

Berdasarkan hasil wawancara dengan ketiga informan di atas, maka dapat disimpulkan bahwa, proses perencanaan anggaran untuk kegiatan pembangunan desa di Desa Moodulio Kecamatan Bone telah berjalan sesuai dengan mekanisme dan tahapan yang mengacu pada ketentuan yang berlaku khususnya Undang-Undang Nomor 60 tahun 2014 tentang penggunaan Dana Desa.

2. Kualitas pelaksanaan penggunaan Dana Desa

Berdasarkan hasil wawancara dengan keempat infoman di atas, maka dapat disimpulkan bahwa kualitas pelaksanaan penggunaan Dana Desa selama ini di Desa Moodulio Kecamatan Bone telah sesuai dengan perencanaan yang telah ditetapkan sebelumnya, dan sifatnya sangat terbuka dan transparan kepada masyarakat. Namun terdapat dua informan yang berbeda dalam hal kualitas penggunaan Dana Desa, kedua informan ini mensinyalir bahwa penggunaan dana desa masih belum maksimal.

3. Kualitas pelayanan aparat desa jika masyarakat menanyakan pelaksanaan program desa yang telah ditetapkan

Berdasarkan penjelasana dari ke empat informan di atas, berkaitan dengan pertanyaan bagaimana kualitas pelayanan 
aparat desa jika masyarakat menanyakan pelaksanaan program desa yang telah ditetapkan, ternyata pemerintah desa sangat terbuka dan transparan, dengan demikian dapat dikatakan bahwa serapan anggaran Dana Desa di Desa Moodulio Kecamatan Bone telah sesuai dengan rencana pemerintah desa serta ketentuan yang berlaku. Namun terdapat satu informan yang berbeda pendapatnya, bahwa kualitas pelayanan masih kurang baik. Pemerintah desa selalu menganggap masyarakat yang kritis dianggap musuh desa.

4. Bentuk pertanggungjawaban penggunaan Dana Desa.

Berdasarkan penjelasan ketiga informan di atas tentang bagaimana bentuk pertanggungjawaban penggunaan Dana Desa selama ini, telah berjalan sesuai dengan ketentuan yang berlaku khususnya mengacu pada Peraturan Menteri Dalam Negeri Nomor 20 Tahun 2018 tentang pengelolaan keuangan desa. Dengan demikian kepuasan masyarakat tentang serapan dana desa sudah sangat baik.

5. Respon masyarakat atas penggunaan Dana Desa

Berdasarkan penjelasan ketiga informan di atas tentang bagaimana respon masyarakat atas penggunaan Dana Desa selama ini, dapat dikatakan bahwa kepuasan masyarakat tentang serapan dana desa sudah sangat baik.

6. Hal-hal apa yang harus diperbaiki dalam pengelolaan Dana Desa

Berdasarkan penjelasan ketiga informan di atas tentang hal-hal apa yang harus diperbaiki dalam pengelolaan Dana Desa kedepan, dapat dikatakan bahwa kepuasan masyarakat tentang serapan dana desa sudah sangat baik, namun untuk meningkatkan pembangunan desa Moodulio perlu peran aktif masyarakat secara langsung, dan oleh sebab itu ditubuhkan keterbukaan serta melalui komunikasi dengan seluruh elemen masyarakat.

\section{Pembahasan}

Manfaat Alokasi Dana Desa menurut Sahdan, dkk. (2006: 6) terdapat beberapa manfaat ADD bagi kabupaten/kota yakni sebagai berikut; a) Kabupaten/Kota dapat menghemat tenaga untuk membiarkan desa mengelola otonominya, tanpa terus bergantung kepada Kabupaten/Kota, b) Kabupaten/Kota bisa lebih berkonsentrasi meneruskan pembangunan pelayanan publik untuk skala luas yang jauh lebih strategis dan lebih bermanfaat untuk jangka panjang

Sedangkan manfaat ADD bagi desa menurut Sahdan, dkk. (2006: 7) sebagai berikut; a) Desa dapat menghemat biaya pembangunan, karena desa dapat mengelola sendiri proyek pembangunannya dan hasil-hasilnya dapat dipelihara secara baik demi keberlanjutannya, b) Tiap-tiap desa memperoleh pemerataan pembangunan sehingga lebih mampu memberikan pelayanan kepada masyarakat desa, c) Desa memperoleh kepastian anggaran untuk belanja operasional pemerintahan desa. Sebelum adanya ADD, belanja operasional pemerintahan pemerintaha desa besarnya tidak pasti, d) Desa dapat menangani permasalahan desa secara cepat tanpa harus lama menunggu datangnya program dari pemerintah Daerah Kabupaten/Kota, e) Desa tidak lagi hanya tergantung pada swadaya masyarakat dalam mengelola persoalan pemerintaha, pembangunan serta sosial kemasyarakatan desa, f) Dapat mendorong terciptanya demokrasi di desa, g) Dapat mendorong terciptanya pengawasan langsung dari masyarakat untuk menekan terjadinya penyimpangan, h) Dengan partisipasi semua pihak, maka kesejahteraan kelompok 
perempuan, anak-anak, petani, nelayan, orang miskin, dan lain-lain dapt tercipta.

\section{Peruntukan Alokasi Dana Desa}

Menurut Sahdan, dkk. (2006: 8) peruntukan ADD adalah sebagai berikut: a) Untuk

biaya pembangunan desa, b) Untuk pemberdayaan masyarakat, c) Untuk memperkuat pelayanan publik di desa, d) Untuk memperkuat partisipasi dan demokrasi desa, e) Untuk tunjangan aparat desa, f)Untuk operasional pemerintahan desa, g) Tidak boleh digunakan untuk kegiatan politik atau kegiatan melawan hukum.

Desa Moodulio yang dipimpinan oleh Karim Kaimo telah menyelenggarakan proses pemerintahan dengan serapan dan alokasi dana desa yang bersumber dari dana APBN dan APBD Sejak tahun 2015 sampai sekarang dengan rincian sebagai berikut:

1. Tahun 2015 Desa Moodulio telah mengelola Dana Desa/APBN Sebesar Rp. 200.016.000 (Dua Ratus Juta Enam Belas Ribu Rupiah), yang telah dialokasikan untuk Membangun Jalan Lingkar Akses Tani di Dusun I dan Dusun IV.(sumber data: APBDes Moodulio Tahun 2015).

2. Pada tahun 2016 desa Moodulio mengelola Dana Desa/APBN sejumlah Rp.675.882.000 (Enam Ratus Tujuh Puluh Lima Juta Delapan Ratus Delapan Puluh Dua Ribu Rupiah),yang digunakan untuk peningkatan sarana dan prasarana untuk masyarakat desa yakni Untuk Pembangunan Jalan Rabat Beton Akses Tani, pembangunan MCK + Sumur Gali dan Pengadaan Rakit/Rumpon. (sumber data: APBDes Moodulio Tahun 2016).

3. Serta pada tahap awal di Tahun 2017 dengan pengelolaan Dana Desa/APBN sebesar Rp. 775.872 .000 (Tujuh Ratus
Tujuh Puluh Lima Juta Delapan Ratus Tujuh Puluh Dua Ribu Rupiah), yang digunakan untuk Pengadaan Honor Guru PAUD dan Guru Ngaji, Pengadaan Perlengkapan Sekolah Anak Miskin, Pengadaan Perlengkapan Rukun Duka, Pengadaan Ternak Sapi Untuk KK Miskin, Pengadaan Lampu Penerang Jalan, Pengadaan Alat Kesehatan Poskesdes dan Pembangunan Draenase.(sumber data: APBDes Moodulio Tahun 2017).

Berdasarkan hasil penelitian yang telah dilakukan menggambarkan bahwa serapan anggaran telah sesuai dengan ketentuan dan peruntukkan yang telah didesain dan ditetapkan melalui mekanisme perencanaan anggaran dimana prosesnya melibatkan seluruh komponen baik masyarakat, pemerintah desa, TPK baik desa maupun kabupaten dalam hal Badan pemberdayaan Desa.

Hasil penelitian menggambarkan pula bahwa kepuasan masyarakat terhadap serapan anggaran sudah sangat baik berdasarkan jawaban para informan, dengan demikian bahwa serapan anggaran Dana Desa di Desa Moodulio Kecamatan Bone Kabupaten Bone Bolango telah berjalan dengan baik dan dapat diterima oleh masyarakat. Walaupun masih ada masyarakat yang masih menganggap bahwa serapan dana desa di Desa Moodulio masih belum transparan. Namun pemerintah desa cukup memahami dengan keberadaan masyarakat yang jumlahnya beberapa orang saja, yang selama ini kritis terhadap semua pelaksanaan pemerintahan desa, termasuk penggunaan dana desa. Bahkan kelompok masyarakat ini merasa bahwa betapun baiknya perlaksanaan pemerintahan khususnya soal anggaran desa. Selalu saja 
mencurigai bahwa penyimpangan selalu terjadi.

Namun secara administratif tidak ditemukan pelanggaran penggunaan dana desa, karena setiap pemeriksaan yang dilakukan baik oleh inspektorat dari kabupaten maupun pengawas dari pusat tidak ditemukan unsur-unsur yang mengarahkan pada penyelewengan hingga saat penelitian ini dilakukan. Jika terdapat masyarakat tidak puas, memang merupakan keniscayaan jika seluruh kebijakan yang ditempuh pemerintah desa akan diterima dengan baik oleh masyarakat. Karena sudah menjadi fakta bahwa setiap pemerintahan termasuk pemerintah desa pasti mengalami tantang dalam menyamakan presepsi masyarakat. Dan hal tersebut merupakan dinamika dalam proses penyelenggaran pemerintahan, terutama jika punya tendensi politik, sehingga pemerintah desa menganggap bahwa itulah tantangan untuk mencapai tujuan pembangunan khususnya di Desa Moodulio Kecamatan Bone Kabupaten Bone Bolango..

\section{KESIMPULAN}

\section{Berdasarkan hasil penelitian dan pembahasan yang telah dilakukan pada} bagian sebelumnya, maka kesimpulan penelitian ini adalah:

Alokasi dana desa (ADD) yang bersumber dari dana perimbangan keuangan pemerintah pusat dan daerah keberadaanya sangat mempengaruhi laju pembangunan setiap desa. Demikian halnya dengan desa Moodulio Kecamatan Bone Kabupaten Bone Bolango dengan adanya ADD saat ini maka desa Moodulio sangat terbantu dalam melaksanakan pembangunan desa secara bertahap demi terwujudnya kesejahteraan masyarakat. Hal ini terlihat pada responsn masyarakat atas serapan ADD yang sangat baik baik dilihat dari aspek transparansi dan keterbukaan, maupun dari aspek pelibatan masyarakat dalam penyusunan rencana pembangunan desa. Pada sisi lainnya terkait keberadaan ADD maka pemerintahan desa Moodulio perlu meningkatkan pengetahuan SDM pemerintahan desa dalam mengelola dan menggunakan keuangan ADD sebagaimana yang diharapkan dari peraturan perundangundangan yang berlaku serta perlu adanya wadah informasih kepada masyarakat sebagai media informasi kepada masyarakat.

\section{SARAN}

Berdasarkan kesimpulan penelitian yang telah diuraikan di atas, maka beberapa saran diajukan sebagai berikut:

1. Kiranya pemerintah pusat dan pemerintah daerah dapat memberikan pengetahuan dibidang pengelolaan keuangan bagi aparatur pemerintahan Desa.

2. Keberadaan ADD pada tiap tahunnya diharapkan dapat terjadi peningkatan.

Pemerintah desa perlu mengakomodir bahkan merangkul kelompok masyarakat yang kritis terhadap penyelenggaran program-program pembangunan desa.

\section{REFERENSI}

Undang-Undang Nomor 6 Tahun 2014 Tentang Desa, Salinan.

Peratutan Pemerintah RI Nomor 60 Tahun 2014 Tentang Dana Desa Yang Bersumber Dari Anggaran Pendapatan Dan Belanja Negara, Salinan.

Peraturan Menteri Desa Nomor 22 Tahun 2016 tentang Prioritas Penggunaan Dana Desa Tahun 2017, Salinan.

Peraturan Menteri Keuangan Nomor 49 Tahun 2016 Tentang Tata Cara Pengalokasian, Penyaluran, Penggunaan, APBDesa, Slinan.

Peraturan Bupati Kabupaten Bone Bolango Nomor 30 Tahun 2016 Tentang 
Penjabaran Anggaran Pendapatan Dan Belanja Negara Kabupaten Bone Bolango Tahun 2017, Salinan.

Pemerintah Desa Moodulio, APBDes Desa Moodulio Tahun Anggaran 2017.

Alma, Buchari. 2011. Manajemen Pemasaran Dan Pemasaran Jasa, Bandung: Alfabeta

Direktorat Jendral Perimbangan Keuangan. 2015. Himpunan Peraturan Perundang-Undangan Mengenai Desa. Kementrian Keuangan. 2.

Lupiyoadi. 2006. Excellent Service Sebagai Kunci Kepuasan Pelanggan. Jakarta

Raco, J.R. 2015. pengantar Conny R. Semiawan. Metode Penelitian Kualitatif. Jenis, Karakteristik dan Keunggulannya. Jakarta: Grasindo

Sahdan, dkk. 2006. ADD untuk Kesejahteraan Rakyat Desa.Yogyakarta: Forum Pengembangan Pembaharuan Desa.

Sugiyono. 2013. Memahami Penelitian Kualitatif. Bandung: Alfabeta 